\title{
KINETIC RESEARCH AND MATHEMATICAL PLANNING ON THE OBTAINING OF POTASSIUM HUMATE FROM BROWN COAL OF THE LENGER DEPOSIT
}

\author{
B.M. Smailov ${ }^{1,}$, M. A. Zharkinbekov ${ }^{2}$, K. T. Tuleshova ${ }^{2}$, N.N. \\ Issabayev $^{3}$, A.S. Tleuov ${ }^{1}$, O. K. Beisenbayev ${ }^{1}$, M.M. Esirkepova ${ }^{1}$ \\ and A.M. Azimov ${ }^{1}$ \\ ${ }^{1}$ M. Auezov South Kazakhstan Kazakhstan State University/ Department of Chemical \\ technologies of inorganic substances, 160012, Shymkent, Kazakhstan \\ ${ }^{2}$ International University SILKWAY/Department of Chemical and Biology, \\ Shymkent, Kazakhstan \\ ${ }^{3}$ Al-Farabi Kazakh National University/Department of Chemistry, Almaty, Kazakhstan \\ ${ }^{\circledR}$ Corresponding Author: smaylov.bakhyt@bk.ru
}

\begin{abstract}
This article provides information about the method of obtaining potassium humate obtaining from brown coal of the Lenger deposit, and also describes the elemental and mineralogical composition of potassium humate determined with SEM (JSM-64901 V, Jeol). Kinetic data on the decomposition of brown coal with solutions of potassium hydroxide are presented. The area of chemical reactions and the activation energy is determined. To determine the accuracy of the process of obtaining potassium humate from Lenger coal waste with the accuracy of experimental data, methods of mathematical planning were used, quadratic functions were established. The advantage of obtaining potassium humate is that they are environmentally safe and have high bioactivity. They are also characterized by a high content of humic substances that are involved in the structure formation of the soil, accelerate biochemical processes, and increase the physical and chemical characteristics in the soil. Under the influence of humate-containing substances, the function of microflora elements in the soil is activated, and the number of beneficial microorganisms increases.
\end{abstract}

Keywords: Humate, Coal Waste, Alkaline Solution, Soil.

RASĀYAN J. Chem., Vol. 14, No.3, 2021

\section{INTRODUCTION}

The research on obtaining new varieties of complex organo-mineral fertilizers based on the products of humus-humic processing of coal mining waste contributes to accelerating the development of the agricultural sector of the country. Research by scientists and industrialists, as well as laboratory experiments, show that industrial waste is a sufficiently valuable secondary raw material for the production of mineral and organic-mineral fertilizers. ${ }^{1-2}$

As a result of coal mining in Kazakhstan, more than 6 million tons of waste was generated, and Lenger's deposit of brown coal is located in south Kazakhstan. According to the data, reserve, its balance part is 33956 thousand tons, the off-balance part - 3244 thousand tons. $^{3}$

Coal-mining waste from the Lenger deposit is a promising and valuable source of organo-mineral raw materials and contains a wide variety of trace elements and organic substances with fertilizing properties, and in this regard is a valuable secondary raw material suitable for processing into humic acid. ${ }^{4-5}$

The main components of brown coal waste from the Lenger deposit are mineral and organic substances. The mineral part is represented by the constituent components of siliceous, aluminate and calcium compounds. The organic part of brown coal waste is represented by functional groups of organic substances, including humic compounds, in complex with organometallic substances.

Currently, humate obtained from coal waste is very popular in agricultural production. Humate is an environmentally friendly substance that improves soil impact, increases fertility, reduces the negative effects of pesticides and helps to increase crop production.

Rasayan J. Chem., 14(3), 1899-1905(2021)

http://doi.org/10.31788/RJC.2021.1436391

This work is licensed under a CC BY 4.0 license. 
RASĀYAN J. Chem.

Vol. 14 | No. 3 |1899-1905| July - September | 2021

Humate is a substance that is synthesized from humic substances. It is humate and acids that are the main chemical constituents of any soil. The effectiveness of most biochemical processes is primarily affected by the quality of humus in the soil. Humic substances in soils are contained in different amounts. On average, the content level is $10-15 \%$, the content in peat is $25-30 \%$, and in brown coal - about $85 \%{ }^{6-7}$

Humic substances that are part of fertilizers contribute to the better assimilation of the main elements of nutrition by plants. They contain trace elements, physiologically-and growth-active substances, form a loose structure in the soil, stimulate the growth and development of plants. Humic substances are also able to adsorb nutrients and moisture while reducing the possibility of leaching nutrients into subsurface horizons. ${ }^{7-8}$

As a result of numerous scientific studies, the ability of humates to influence vegetation, water and the soil itself in various ways has been proven. Among them: preventing the penetration of poisons and heavy metals; increasing the proportion of nutrients; activating crop growth; changing the shade of the soil to a darker one, which increases its heating from sunlight; improving the quality and quantity of the crop. ${ }^{9}$

\section{EXPERIMENTAL}

To obtain potassium humate, experimental physicochemical and analytical research methods were selected: electron microscopy, IR spectroscopy, elemental analysis, etc. The elemental and mineralogical composition of coal waste was determined using a JSM-64901 V (SEM) scanning electron microscope (Table-1).

Table-1: Elemental and Mineralogical Composition of Coal Waste from Lenger Deposit

\begin{tabular}{c|c|c|c}
\hline Element & Weight \% & Oxides & In terms of oxides, \% \\
\hline $\mathrm{C}$ & 42,96 & - & - \\
\hline $\mathrm{O}$ & 39,66 & - & - \\
\hline $\mathrm{Na}$ & 0,14 & $\mathrm{Na}_{2} \mathrm{O}$ & 0,19 \\
\hline $\mathrm{Mg}$ & 0,30 & $\mathrm{MgO}$ & 0,50 \\
\hline $\mathrm{Al}$ & 3,92 & $\mathrm{Al}_{2} \mathrm{O}_{3}$ & 7,40 \\
\hline $\mathrm{Si}$ & 8,06 & $\mathrm{SiO}_{2}$ & 17,27 \\
\hline $\mathrm{S}$ & 0,89 & $\mathrm{SO}_{3}$ & 1,78 \\
\hline $\mathrm{K}$ & 0,67 & $\mathrm{~K}_{2} \mathrm{O}$ & 0,80 \\
\hline $\mathrm{Ca}$ & 1,05 & $\mathrm{CaO}$ & 1,47 \\
\hline $\mathrm{Ti}$ & 0,26 & $\mathrm{TiO}_{2}$ & 0,43 \\
\hline $\mathrm{Fe}$ & 2,09 & $\mathrm{Fe}_{2} \mathrm{O}_{3}$ & 2,98 \\
\hline
\end{tabular}

From the analysis of Table-1, it follows that the elemental composition of the sample of coal waste from the Lenger deposit contains in\%: C - 42.96, Fe-2.09, Mg-0.30, etc. This content of elements in the composition of coal waste is sufficient to use it as a raw material for the production of humate-containing fertilizers ${ }^{10}$.

The process of obtaining potassium humate and humic substances from the Lenger coal waste was carried out under laboratory conditions following GOST 9517-94. The process of obtaining potassium humate is carried out by continuous mixing at a temperature of $40-80^{\circ} \mathrm{C}$ for $80-120$ minutes. Due to an increase in the concentration of alkali used in the production of potassium humate, the yield of the resulting potassium humate increases. ${ }^{11-13}$ The results of the experimental work are shown in Table-2.

Table-2: Alkali Concentration at the Output of Potassium Humate and Temperature Dependence

\begin{tabular}{c|c|c|c|c}
\hline Temperature, ${ }^{0} \mathrm{C}$ & The Yield of potassium & \multicolumn{3}{|c}{ Concentration of Potassium Hydroxide, \% } \\
\cline { 4 - 5 } & humate in the total & 1 & 3 & 5 \\
\cline { 4 - 5 } & amount, $\%$ & 77,35 & 81,22 & 91,25 \\
\cline { 4 - 5 } & & 79,28 & 84,98 & 94,37 \\
\cline { 3 - 5 } & & 80,22 & 87,32 & 96,67 \\
\hline 80 & & &
\end{tabular}

Table- 1 shows that at $5 \%$ of the alkali concentration and a temperature of $80{ }^{\circ} \mathrm{C}$, the yield of potassium humate is $96.67 \%$. During the extraction process, there is no need to further increase the concentration of alkali, since, firstly, the chemical composition of humate in the maximum amount, and secondly, the 
RASĀYAN J. Chem.

Vol. 14 | No. 3 |1899-1905| July - September | 2021

consumption of alkali required for the process increases. Chemism of this process can be described in the following way:

$$
\mathrm{CW}+\mathrm{KOH} \rightarrow \mathrm{HA}-\mathrm{COOK}
$$

Where: CW - coal waste; HA - COOK - potassium humate

The elemental and mineralogical composition of the resulting potassium humate was determined using an electron microscope (JSM-64901 V, Jeol. Japan). The results of the study are shown in Table-3.

Table-3: Elemental and Mineralogical Composition of Potassium Humate

\begin{tabular}{c|c|c|c}
\hline Element & Weight $\%$ & Oxides & In terms of oxides, $\%$ \\
\hline $\mathrm{C}$ & 54,02 & - & - \\
\hline $\mathrm{O}$ & 23,26 & - & - \\
\hline $\mathrm{K}$ & 19,41 & $\mathrm{~K}_{2} \mathrm{O}$ & 23,4 \\
\hline $\mathrm{Na}$ & 0,29 & $\mathrm{Na}_{2} \mathrm{O}$ & 0,39 \\
\hline $\mathrm{Al}$ & 0,62 & $\mathrm{Al}_{2} \mathrm{O}_{3}$ & 1,17 \\
\hline $\mathrm{Si}$ & 0,94 & $\mathrm{SiO}_{2}$ & 2,01 \\
\hline $\mathrm{S}$ & 0,88 & $\mathrm{SO}_{3}$ & 2,20 \\
\hline $\mathrm{Fe}$ & 0,58 & $\mathrm{Fe}_{2} \mathrm{O}_{3}$ & 0,83 \\
\hline
\end{tabular}

Table- 2 shows that in the composition of potassium humate, the content of carbon (C) is $54.02 \%$, potassium $(\mathrm{K})$ is $19.41 \%$, etc. This content of elements in the composition of potassium humate is sufficient for its use as humate-containing components.

\section{RESULTS AND DISCUSSION}

The experimental data on the process of obtaining potassium humate was processed according to the Pavlyuchenko equation (2), the kinetic regularities of the process were determined, with the calculation of the values of the "apparent" activation energy (3).

$$
\begin{aligned}
& 1-(1-\alpha)^{1 / 3}=\mathrm{K}^{*} \tau^{1 / 2} \\
& \mathrm{~K}=\mathrm{A}_{0} * \mathrm{e}^{-\mathrm{E} / \mathrm{RT}}
\end{aligned}
$$

Where, E - "apparent" activation energy, $\mathrm{kJ} / \mathrm{mol}$; R- is a constant value of 8.314 and $\mathrm{T}$ - is the process temperature. The dependence of the consumption of potassium humate on the yield of the alkali concentration and temperature during the extraction of the Lenger coal waste with a solution of potassium hydroxide is shown in Fig.-1.



Fig.-1: Potassium Humate yield as a Function of Temperature and Concentration

The Pavlyuchenko equation is used to determine the rate of the chemical reaction constant and the energy activation "apparent" during the dissolution of the Lenger coal and potassium hydroxide waste. Table-4 
RASĀYAN J. Chem.

Vol. 14 | No. 3 |1899-1905| July - September | 2021

shows the results of the process of dissolution of the Lenger coal waste obtained by the method of the Pavlyuchenko equation. ${ }^{14}$

Table-4: Processed results using the Pavlyuchenko Equation Method

\begin{tabular}{c|c|c|c|c|c}
\hline$\alpha$ & $1-\alpha$ & $(1-\alpha)^{1 / 3}$ & $1-(1-\alpha)^{1 / 3}$ & $\tau, \min$ & $\sqrt{\tau}$ \\
\hline \multicolumn{7}{c}{$\mathrm{T}=313 \mathrm{~K}$} \\
\hline 0,7735 & 0,2265 & 0,6095 & 0,3505 & 80 & 8,944 \\
\hline 0,7928 & 0,2072 & 0,5919 & 0,4081 & 100 & 10,00 \\
\hline 0,8022 & 0,1978 & 0,5826 & 0,4174 & 120 & 10,95 \\
\hline \multicolumn{7}{c}{$\mathrm{T}=333 \mathrm{~K}$} \\
\hline 0,8122 & 0,1878 & 0,5726 & 0,3874 & 80 & 8,944 \\
\hline 0,8498 & 0,1502 & 0,5315 & 0,4685 & 100 & 10,00 \\
\hline 0,8732 & 0,1268 & 0,5023 & 0,4977 & 120 & 10,95 \\
\hline \multicolumn{7}{|c|}{$\mathrm{T}=353 \mathrm{~K}$} \\
\hline 0,9125 & 0,0875 & 0,4438 & 0,4762 & 80 & 8,944 \\
\hline 0,9437 & 0,0563 & 0,3832 & 0,6168 & 100 & 10,00 \\
\hline 0,9667 & 0,0333 & 0,3217 & 0,6783 & 120 & 10,95 \\
\hline
\end{tabular}

In Fig.-2 below, the rate constants of chemical reactions are established by drawing parallel lines to the abscissa axis on the curves $\mathrm{T}_{1}-313 \mathrm{~K}, \mathrm{~T}_{2}-333 \mathrm{~K}, \mathrm{~T}_{3}-353 \mathrm{~K}$ by detecting the tangent of the intersection angle based on the equations.

The rate determined by the equation and the constants shown by the graphical method was determined by processing the activation energy of the process.

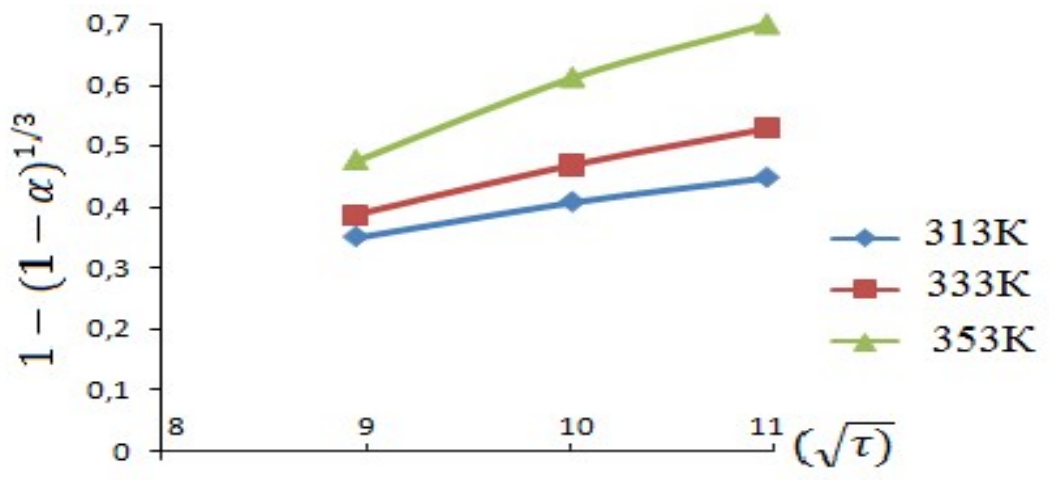

Fig.-2: Dependencies between $1-(1-\alpha)^{1 / 3}=\sqrt{\tau}$

Table-5: Relationship between the Value of the Rate Constant and the Return Temperature

\begin{tabular}{c|c|c|c|c}
\hline Constant Speed & Numerical Value, $K$ & $\ln K$ & Temperature, $\mathrm{K}$ & $1 / T$ \\
\hline $\operatorname{tg}_{\varphi 1}=\mathrm{K}_{1}$ & 0,0391 & $-3,241$ & 343 & 0,0029 \\
\hline $\operatorname{tg}_{\varphi 2}=\mathrm{K}_{2}$ & 0,0442 & $-3,119$ & 353 & 0,0028 \\
\hline $\operatorname{tg}_{\varphi 3}=\mathrm{K}_{3}$ & 0,0616 & $-2,787$ & 363 & 0,0027 \\
\hline
\end{tabular}

Based on the data in Table-3, a graph of the relationship between $\ln \kappa=f(1 / T)$ is made.

To ensure the accuracy of the results of experimental work in the processing of coal waste, mathematical planning methods were used. For this, based on the 2 nd orthogonal plan, the following conditions were met: the upper limit value $\alpha=1.414$, the total number of experiments $\mathrm{N}=14$. The yield of potassium humate, $\%$, in the following cases: $\mathrm{z}_{1}$ - temperature $\left(40-80^{\circ} \mathrm{C}\right), \mathrm{z}_{2}$ - extraction time $(80-120 \mathrm{~min}) \mathrm{z}_{3}$ - alkali concentration (1-5\%).

The regression equation obtained on the basis of the developed method of mathematical planning:

$$
y=96,71+0,64 x_{1}+x_{2}+4,96 x_{3}-0,48 x_{1}^{2}-0,77 x_{2}^{2}-2,11 x_{3}^{2}
$$


RASĀYAN J. Chem.

Vol. 14 | No. 3 |1899-1905| July - September | 2021

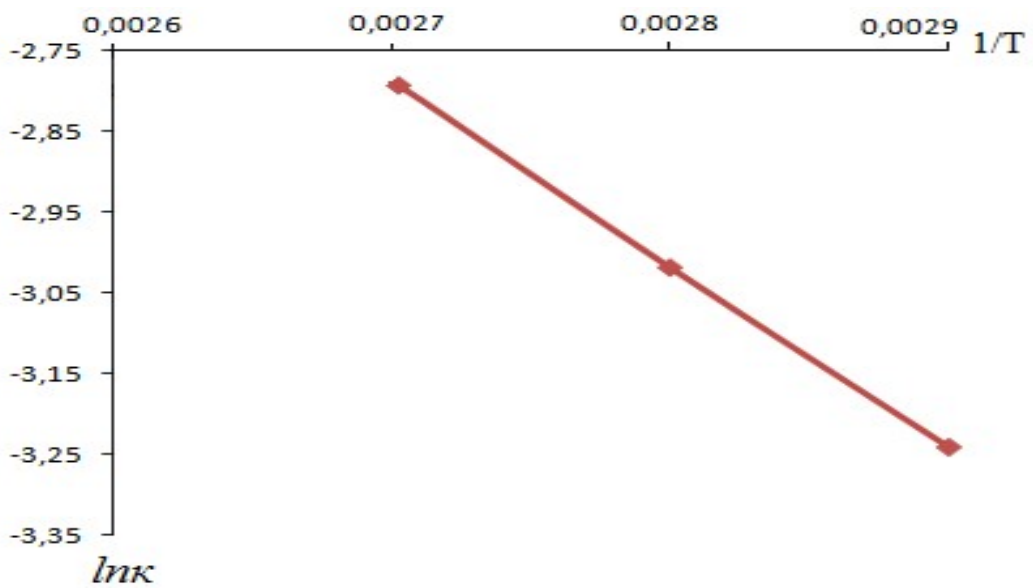

Fig.-3: Dependencies between $\ln \kappa=f(1 / T)$

Table-6: Coefficient of the Regression Equation

\begin{tabular}{c|c|c|c|c|c|c}
\hline $\mathrm{x}_{1}$ & $\mathrm{x}_{2}$ & $\mathrm{x}_{3}$ & $\mathrm{z}_{1}$ & $\mathrm{Z}_{2}$ & $\mathrm{z}_{3}$ & $\mathrm{y} 1(\mathrm{Kp})$ \\
\hline 1 & 1 & 1 & 79,8 & 115,77 & 1 & 80,21 \\
\hline-1 & 1 & 1 & 68,7 & 115,77 & 1 & 77,87 \\
\hline 1 & -1 & 1 & 64,87 & 71,68 & 1 & 75,28 \\
\hline-1 & -1 & 1 & 30,13 & 63,18 & 1 & 71,45 \\
\hline 1 & 1 & -1 & 54,87 & 106,82 & 0,9 & 65,32 \\
\hline-1 & 1 & -1 & 30,13 & 115,77 & 2,9 & 89,90 \\
\hline 1 & -1 & -1 & 79,8 & 43,18 & 2,9 & 88,62 \\
\hline-1 & -1 & -1 & 30,13 & 43,18 & 2,9 & 75,22 \\
\hline 1,414 & 0 & 0 & 80 & 75 & 3 & 80,75 \\
\hline$-1,414$ & 0 & 0 & 40 & 75 & 3 & 75,20 \\
\hline 1 & 1,414 & 1 & 79,8 & 120 & 5 & 96,71 \\
\hline 1 & $-1,414$ & 0 & 79,8 & 80 & 5 & 88,45 \\
\hline 0 & 0 & 1,414 & 42,5 & 80 & 5 & 93,37 \\
\hline 0 & 0 & $-1,414$ & 42,5 & 80 & 5 & 85,41 \\
\hline
\end{tabular}

Table-7: Coefficient of the Regression Equation

\begin{tabular}{c|c|c|c|c|c}
\hline Coefficient & y1 & Coefficient & y1 & Coefficient & y1 \\
\hline b0 & 96,71 & b12 & $-0,257$ & b22 & $-0,768$ \\
\hline b1 & 0,641 & b13 & 0,120 & b33 & $-2,107$ \\
\hline b2 & 1,000 & b23 & 0,020 & - & - \\
\hline b3 & 2,757 & b11 & $-0,479$ & - & - \\
\hline
\end{tabular}

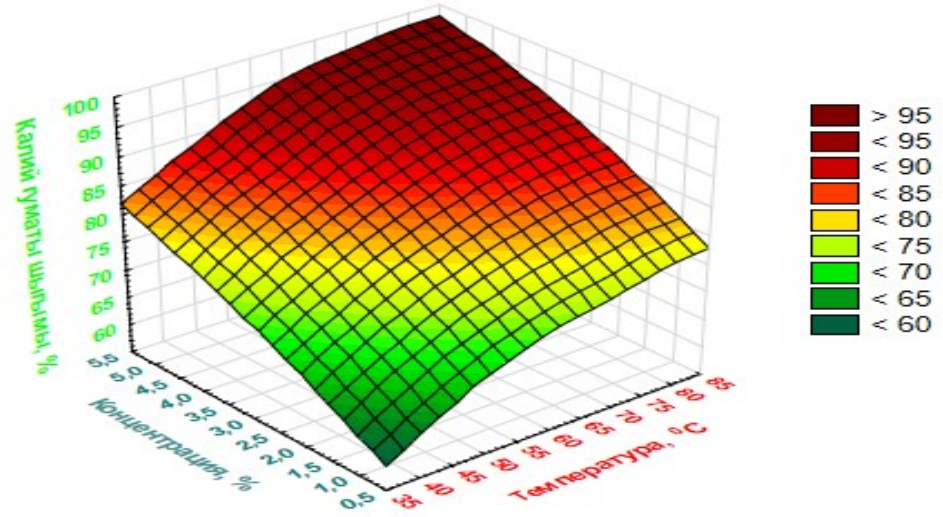

Fig.-4: Dependence of the Yield of Potassium Humate on the Processing Time, Temperature and Alkali Concentration 
From Fig.-4 it follows that the yield of potassium humate, obtained with a change in time, temperature and concentration during the decomposition of Lenger coal waste, is characterized by a change in the square of the plane from green to dark red.

It was determined that the yield of potassium humate at $5 \%$ of the alkali concentration is $96.67 \%$ at a temperature of $80^{\circ} \mathrm{C}$. The elemental and mineralogical composition of potassium humate obtained according to GOST 9517-94 was determined using an electron microscope (JSM-64901 V, Jeol. Japan).

The resulting regression equation makes it possible to determine whether it is possible to achieve a high yield by determining the influence of all factors affecting the process of obtaining potassium humate. According to the results of experimental work based on the method of mathematical planning, it was found that the optimal indicator of the extraction process of potassium humate at a temperature of $80{ }^{\circ} \mathrm{C}$ and a time of 120 minutes is $96.71 \%$ potassium humate at a potassium concentration of $5 \%$ hydroxide solution. ${ }^{15}$

To determine the accuracy of the process of obtaining potassium humate from Lenger coal waste with the accuracy of experimental data, methods of mathematical planning were used, quadratic functions were established.

The proposed solution makes it possible to obtain potassium humate with the necessary content of humic substances and trace elements, dispose of man-made waste, reduce the cost and simplify the process, as well as minimize the formation of production waste. The proposed solution makes it possible to obtain potassium humate with the necessary content of humic substances and microelements, to dispose of manmade waste, to reduce the cost and simplify the process, and also to minimize the formation of production waste. $^{16-17}$

\section{CONCLUSION}

The energy of the "activity" of the extraction process of Lenger coal waste with a solution of potassium hydroxide using the graphical method $\operatorname{LnK}=\mathrm{f}(1 / \mathrm{T})$ and Pavlyuchenko equations are determined. The energy value of the "activity" of the chemical reaction is equal to "apparent" activation energy $\mathrm{E}=7.69$ $\mathrm{kJ} / \mathrm{mol}$. Based on the data obtained, the chemical reaction of brown coal decomposition with potassium hydroxide was detected in the diffusion region.

The benefits of potassium humate are that they are environmentally safe and have high bioactivity. Potassium humate accelerates biochemical processes, as well as increases the physical and chemical characteristics in the soil. Under the influence of potassium humate, the function of microflora elements in the soil is activated, and the number of beneficial microorganisms increases ${ }^{18-19}$.

The method of processing coal waste to obtain potassium humates and their use in growing to increase the yield of crops has been studied.

It was established, that the microfertilizer obtained is characterized by a high content of humic substances, which participate in soil structurization, accumulation of nutritious elements and microelements in the assimilable form, promote regulation of geochemical streams of metals in water and soil ecosystems. ${ }^{20}$

\section{REFERENCES}

1. S. S. Fong, L. S. Wong, N. Ch. Janice, A. M. Faizal, Journal of the Brazilian Chemical Society, 17(3), 582(2006), https://doi.org/10.1590/S0103-50532006000300023

2. U.B. Nazarbek, Development of Phosphorus Sludge Processing Technologies for Targeted Fertilizer Products: Monograph: Department Chemical Technology of Inorganic Substances, M. Auezov South Kazakhstan State University, Shymkent, Kazakhstan, pp. 89-90, (2017).

3. O.K. Beisenbayev, A.B. Issa and E. Kovaleva, Oriental Journal of Chemistry, 31(4), 2369(2015), https://doi.org/10.13005/ojc/310466

4. T.A. Kuharenko, Solid Fuel Chemistry 3(6), 87(1980).

5. https://agro-mart.kz/guminovye-udobreniya/acces.15.04.2021

6. F. J Stevenson, Geological Journal, 692(1985), https://doi.org/10.1002/gj.3350210213

7. Gan Cheng, Zeyu Niu, Chuanxiang Zhang, Xiaoming Zhang and Xusheng Li, Applied Sciences 9(7), 1356 (2019), https://doi.org/10.3390/app9071356

8. R. Shahryari, A. Gadimov, E. Gurbanov and M. Valizade, Asian Journal of Food and Agro-Industry Special Issue, 164(2009) 
RASĀYAN J. Chem.

Vol. 14 | No. 3 |1899-1905| July - September | 2021

9. D. Kumar, A.P. Singh, P. Raha, A. Rakshit, C.M. Singh and P. Kisho, International Journal of Agriculture, Environment \& Biotechnology, 6(3), 441(2013), https://doi.org10.5958/j.2230732X.6.3.015

10. B.M. Smailov, O.K.Beisenbayev, A.S. Tleuov, B.S. Zakirov, Chemical Journal of Kazakhstan, 1(69), 48(2020).

11. GOST 9517-94, Solid Fuel, Methods for Determining the Yield of Humic Acids.

12. E.O. Dzhakipbekov, S.A. Sakibayeva, N.O. Dzhakipbekova, G.F. Sagitova, K.A. Bekzhigitova and Zh.A.Shingisbayeva, Rasayan Journal of Chemistry, 14(1), 1(2021), http://dx.doi.org/10.31788/RJC.2021.1415824

13. RF Patent No. 2579201 IPC C05F11 / 02, Method for Producing Potassium Humate and Installation / Predtechensky A.R., Shikulo M.A.

14. V.M. Shevko, Processing the Results of Kinetic Studies, Chimkent: Kazakh Chemical and Technological Institute, pp. 29, 1990.

15. A. Roine, Outokumpu HSC Chemistry for Windows, Chemical Reaction and Eguilibrium loftware with Extensive Thermochemical Datebase, Pori: Outokumpu Resaerch OY, 2002.

16. E. Dzhakipbekov, S. Sakibayeva, N. Dzhakipbekova, B.Tarlanova, G. Sagitova and Zh. Shingisbayeva, Rasayan Journal of Chemistry, 13(3), 1417(2020), http://dx.doi.org/10.31788/RJC.2020.1325709

17. O.K. Beysenbayev, A.S. Tleuov, B.M. Smailov, B.S. Zakirov, International Scientific and Practical Conference «Fundamental and Applied Scientific Research». - Berlin, pp. 45-51(2019).

18. O.K. Beysenbayev, U.K. Ahmedov, A.B. Issa, B.M. Smailov, M. M. Esirkepova, Zh. K. Artykova, News of the National Academy of Sciences of the Republic of Kazakhstan, Series of Geology and Technical Sciences, 6(438), 36(2019).

19. O.K.Beysenbayev, S.I.Umirzakov, A.S. Tleuov, B.M.Smaylov, A.B.Issa, Kh. Dzhamantikov, B.S. Zakirov, News of the National Academy of Sciences of the Republic of Kazakhstan, Series of Geology and Technical Sciences, 1(433), 80(2019), http://doi.org/10.32014/2019.2518-170X.10

20. B.M. Smailov, O.K. Beisenbayev, A.S.Tleuov, A.A Kadirbaeva, B.S. Zakirov and B. Mirzoyev, Rasayan Journal of Chemistry, 13(3), 1372(2020), http://doi.org/10.31788/RJC.2020.1335726

[RJC-6391/2021] 